\title{
The relationship between and evolution of surface water and groundwater in Songnen Plain, Northeast China
}

\author{
Bing Zhang • Xianfang Song $\cdot$ Yinghua Zhang • \\ Dongmei Han · Changyuan Tang · Lihu Yang • \\ Zhong-Liang Wang
}

Received: 25 May 2014/ Accepted: 24 December 2014/Published online: 7 January 2015

(C) Springer-Verlag Berlin Heidelberg 2015

\begin{abstract}
To improve water management, the relation and the hydrochemical evolution of surface water and groundwater were studied in the Songnen Plain. The surface water and groundwater samples were evaluated for stable isotopes and hydrochemistry analyses. The stable isotopic compositions $\left(\delta^{18} \mathrm{O}, \delta \mathrm{D}\right)$ indicate the groundwater recharges from the precipitation. However, the connectivity between surface water and groundwater is weak, because of the clay layer and the interrupted aquifer. The water evolution is from $\mathrm{Ca}-\mathrm{Mg}-\mathrm{HCO}_{3}$ to $\mathrm{Na}-\mathrm{HCO}_{3}$ by the evaporation, water-rock interaction, and ion exchange processes. The water evaporation and leaching of salinealkaline soil are the main reasons for water salinity. Further, the leaching of salts in the soil during recharging from backwater and irrigation water intensifies the salinization. The relationship between and evolution of surface water and groundwater provide important guidance for water management not only in the arid and semi-arid area, but also in the soda saline-alkali soil regions of the world.
\end{abstract}

\footnotetext{
B. Zhang · Z.-L. Wang

Tianjin Key Laboratory of Water Resources and Environment,

Tianjin Normal University, 300387 Tianjin, China

e-mail: bzhangchina@gmail.com

B. Zhang $\cdot$ X. Song $(\bowtie) \cdot$ Y. Zhang $\cdot$ D. Han $\cdot$ L. Yang

Key Laboratory of Water Cycle and Related Land Surface Processes, Institute of Geographic Sciences and Natural Resources Research, Chinese Academy of Sciences, 100101 Beijing, China

e-mail: songxf@igsnrr.ac.cn

C. Tang

Departments of Environmental Science and Landscape Architecture, Faculty of Horticulture, Chiba University, Chiba 271-8510, Japan
}

Keywords Surface water and groundwater . Hydrochemical evolution - Stable isotopes . Water management $\cdot$ Songnen Plain

\section{Introduction}

Surface water and groundwater are the main water resources. Groundwater plays an increasingly important role in the domestic, industrial and agricultural water supply. Further, groundwater forms an important part of the hydrologic cycle (Bruce 2011). In the hydrological cycle, groundwater continuously interacts with multiple spheres through physical and chemical processes. Research on the hydrochemical processes governing groundwater is a vital task to water and environment management (Zhang et al. 2007). The groundwater exchanges with the river channel creating gaining, losing, flow through and parallel flow reaches in the fluvial plain (Woessner 2000). The relationship between surface water and groundwater is complex according to the surrounding environment and groundwater flow regimes (Sophocleous 2002; Anderson 2005; Banks et al. 2011). The stable isotopic and hydrochemical compositions provide the characteristic fingerprint of water movement in the hydrological cycle. The stable isotopes and hydrochemistry are widely applied to study the linkage between surface water and groundwater (Ayenew et al. 2008; Baskaran et al. 2009; Banks et al. 2011). The assessment of the interrelation between surface water and groundwater provides information for water resource management (Winter et al. 1998).

The Songnen Plain is one of the main bases for grain production and animal husbandry in northeastern China (Wang et al. 2004). It is one of the three major regions of 

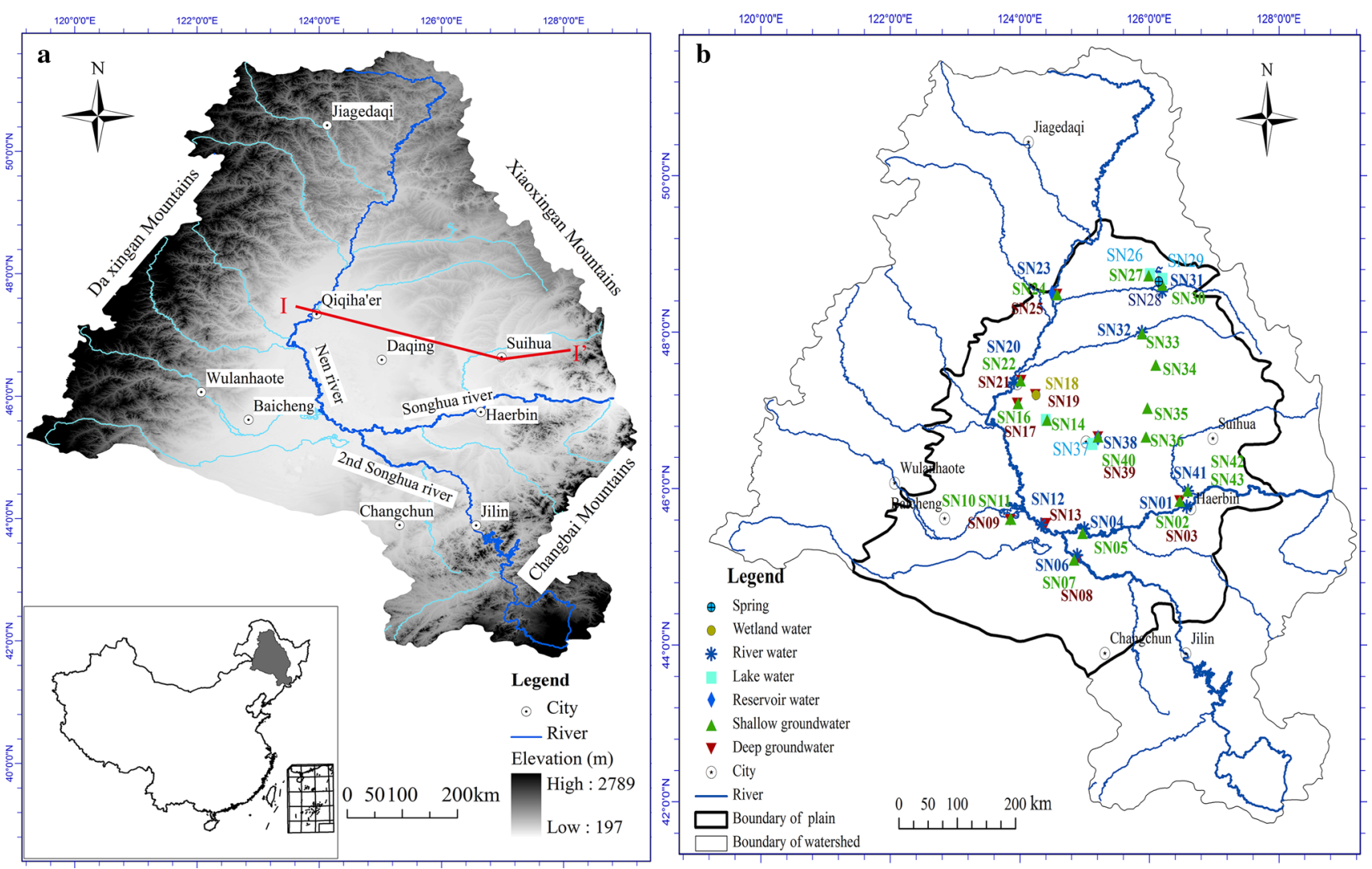

Fig. 1 The location of Songnen Plain (a) and the distribution of water samples (b)

occurrence of soda saline-alkali soil in the world (Zhang et al. 2007). Natural factors of alkalization are parent materials, topographic positions, freeze-thaw action, wind conveyance, water properties and semi-arid/sub-humid climate. Anthropogenic causes are mainly population pressure, overgrazing, and improper agricultural and economic policies (Wang et al. 2009). Because of water shortage and expenditure problems, local farmers have abstracted groundwater with high salinity from the unconfined aquifer for irrigation in the dry land. Thus, a large area of secondary saline-alkaline land has been induced and the slightly saline-alkaline land has been aggravated (Zhang et al. 2007).

The study of the relationship between and evolution of groundwater and surface water is the basis to understand the soil alkalization and water quality degradation. Groundwater issues are well documented in the literatures (Zhang et al. 2007; Xiao et al. 2009; Chen et al. 2010; Liu et al. 2011). However, the combined study of surface water and groundwater has been little documented (Zhang et al. 2012). The stable hydrogen and oxygen isotopic compositions and hydrochemical concentrations have been characterized in the paper. The particular purpose of this study is to (1) understand the relationship between surface water and groundwater; (2) discuss the hydrochemical evolution for water quality and salinity and (3) the sustainable water management in the semi-arid/sub-humid area and the soda saline-alkali soil regions.

\section{Study area}

Study site description

The Songnen Plain $\left(121^{\circ} 27^{\prime}-128^{\circ} 12^{\prime} \mathrm{E}, 43^{\circ} 36^{\prime}-49^{\circ} 45^{\prime} \mathrm{N}\right)$ is underlain by alluvial, lacustrine, and aeolian deposits and is located in the central part of Northeast China (Fig. 1a). The plain has the Changbai Mountains in the east, Daxingan (Greater Khingan) Mountains in the west, Xiaoxingan (Lesser Khingan) Mountains in the north and Songliao watershed divide in the south. The total area is $1.87 \times 10^{5} \mathrm{~km}^{2}$, including Heilongjiang Province and Jilin Province in the district. The main cities in the area are Haerbin, Changchun, Qiqiha'er, Daqing, and Suihua. The total population of the area was 32.31 million in 2003 (Xiao et al. 2009).

The Songnen Plain has a semi-humid and semi-arid continental monsoon climate. The mean annual precipitation is $350-600 \mathrm{~mm}$, with $70-80 \%$ of precipitation occurring during June to September (Fig. 2). The average 
Fig. 2 The daily precipitation and discharge of the Songhua River at the Haerbin hydrologic station

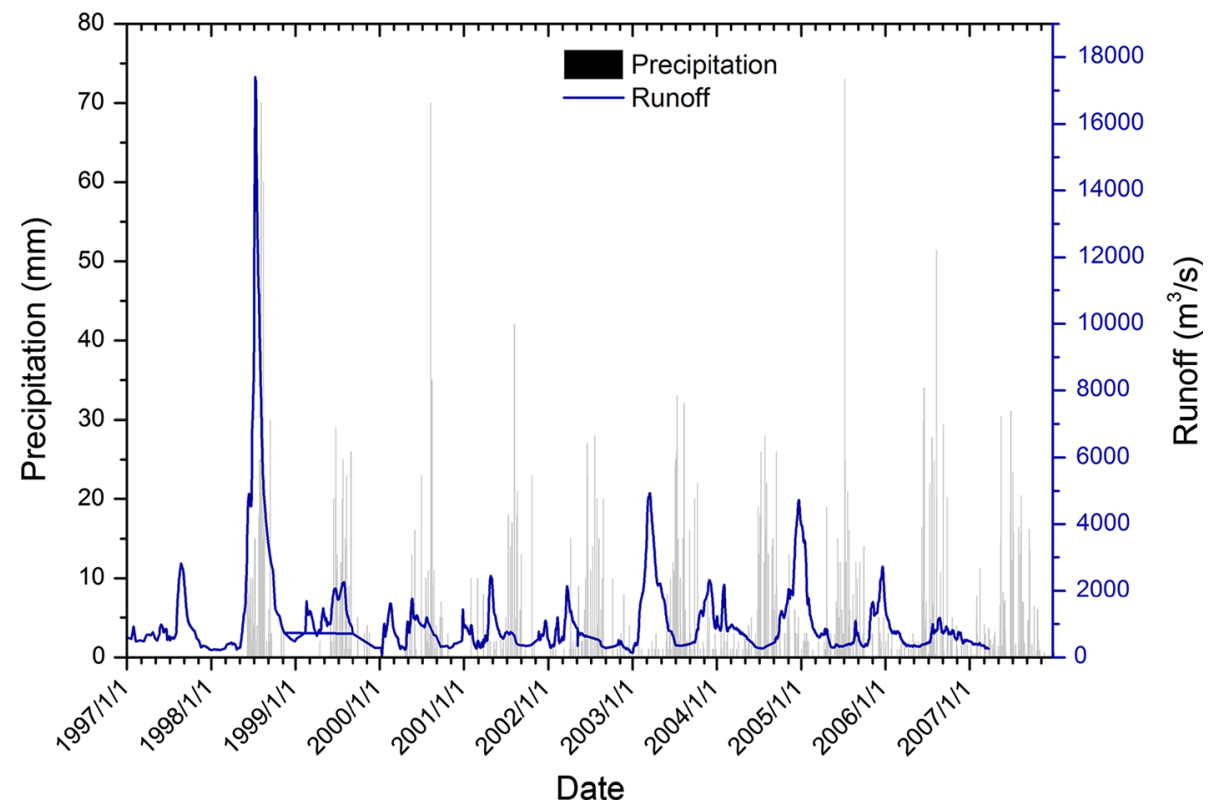

annual temperature is about $4.0-5.5^{\circ} \mathrm{C}$. The average temperature in January is -16 to $-26^{\circ} \mathrm{C}$, while the average temperature in July is $21-23{ }^{\circ} \mathrm{C}$. The evaporation from the water surface is between 700 and 1,100 $\mathrm{mm}$. The Songnen Plain belongs to the drainage of the Songhua River. The second Songhua River and Nen River merge in the center of the area and then compose the Songhua River. The discharge rate at Haerbin station is 40.8 billion $\mathrm{m}^{3} / \mathrm{a}$ (Xiao et al. 2009).

The main types of soils in the area include black soil, chernozem, meadow soil, swamp soil, halic soil, sandy soil and paddy soil. The typical zonal soils are black soil and chernozem. The grasslands are mainly in the west of the Songnen Plain and interlaced with farmland. The landscape vegetation is Leymus chinesis meadow in the area ( $\mathrm{Li}$ and Zhou 2001). The majority of upland crops are wheat, corn, and soybean. The crop growing season is generally from May to September. The average grain yields of rice, wheat, corn and soybean over the period 1978-2008 were 5.23, $2.81,4.36$ and $1.82 \mathrm{t} / \mathrm{ha}$, respectively (Heilongjiang land reclamation bureau 2009).

\section{Hydrogeology}

The Songnen Plain is an alluvial and lacustrine plain that developed on the base of a faulted basin in the Mesozoic. The neotectonic movement of the Songnen Plain was characterized by subsidence in the Pleistocene. The rivers in the basin flowed to the center of the basin. Thick bedded sediment was deposited in the basin, and the outwash piled on the piedmont slope of the Daxingan
Mountains and constituted a primeval outwash fan (Zhang and Wang 2001). The lake deposits shrank to the center of the basin, and alluvial deposit formed widely in the west low plain. The low plain shifted to the development of a fluvial and estuarine delta environment in the Epipleistocene (Zhang and Wang 2001). The groundwater in the Songnen Basin aquifer is a unified groundwater system. The groundwater flows from the east, north, and west mountain areas into the central basin. The groundwater mainly discharges to rivers at the confluence of the second Songhua River and Nen River (Yuan 2006).

There are four aquifers with different hydraulic relationships through aquitards, including Quaternary unconfined aquifer, confined aquifer, Neogene Taikang Group confined aquifer and Da'an Group confined aquifer (Xiao et al. 2009). The thickness of the upper Pleistocene sand aquifer is 1-20 $\mathrm{m}$ with the upper layer of sand clay in the Songnen central plain (Fig. 3). The depth from the land surface to the groundwater table is $<5 \mathrm{~m}$ in the unconfined aquifer. The middle Pleistocene gravel confined aquifer is $30-100 \mathrm{~m}$, with clay in the upper layer. The depth from the land surface to the groundwater table is $<10 \mathrm{~m}$ in the confined aquifer. The lower Pleistocene glutenite confined aquifer is $10-100 \mathrm{~m}$ thick, with an upper clay layer. The depth from the land surface to the groundwater table is $1-10 \mathrm{~m}$ in the confined aquifer (Zhang et al. 1991). The unconfined groundwater table drops $2-5 \mathrm{~m}$, and the confined groundwater table declines $1-2 \mathrm{~m}$ due to the intense groundwater withdraw (Zhao et al. 2010). 
Fig. 3 The geological schematic graph of cross section $\mathrm{I}-\mathrm{I}^{\prime}$

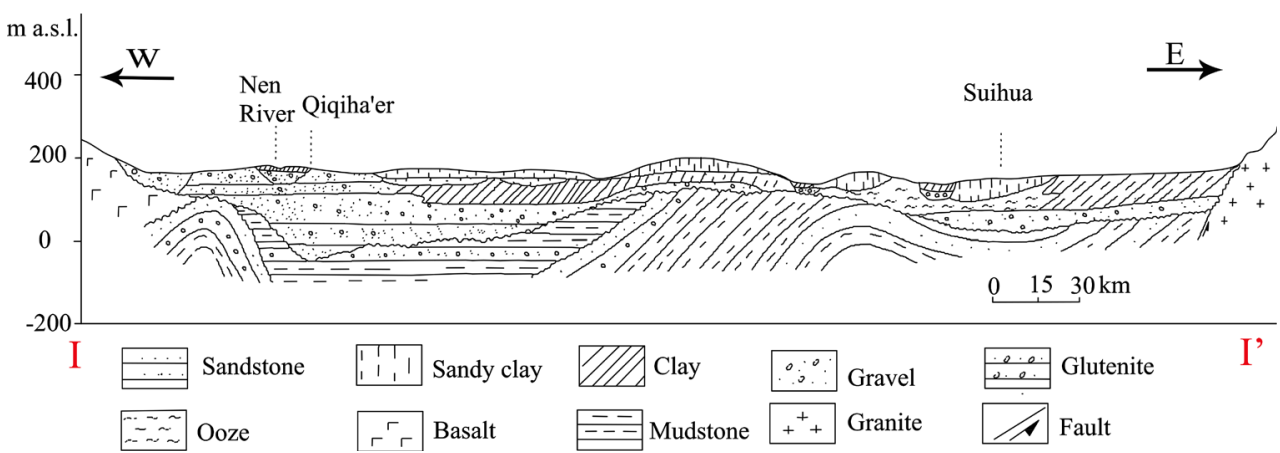

\section{Methods}

Water sampling

The surface water and groundwater were sampled along the Songhua River, the second Songhua River, and Nen River for stable isotope and major ion analysis during August 2010 (Fig. 1b). The surface water was sampled in rivers, lakes and reservoirs. The wetland water was collected in the Zhalong Nature Preserve, Qiqiha'er City, Heilongjiang Province. The shallow and deep groundwater samples were collected from shallow (sampling depth $<60 \mathrm{~m}$ ) and deep (sampling depth $\geq 60 \mathrm{~m}$ ) wells, respectively. One $100 \mathrm{~mL}$ polyethylene bottle with watertight caps was used to store filtered $(0.45 \mu \mathrm{m}$ Millipore membrane filter) water for stable hydrogen and oxygen isotope analysis. Two $50 \mathrm{~mL}$ polyethylene bottles with watertight caps were used to store filtered water for cation and anion analysis. One bottle was acidified with $\mathrm{HCl}$ to $\mathrm{pH} \sim 2$ for cation determination. The other bottle for anion analysis was kept unacidified. All samples were stored at $4{ }^{\circ} \mathrm{C}$ after bottling.

\section{Analytical methods}

\section{Field measurement indices}

The field measurement indices, including electrical conductivity (EC), $\mathrm{pH}$ and water temperature ( $\mathrm{T}$ ), were measured in situ via an $\mathrm{EC} / \mathrm{pH}$ meter (WM22EP, Toadkk, Japan). The oxidation-reduction potential (ORP) and dissolved oxygen (DO) were measured by pH3110 and Oxi3310, respectively (WTW, Germany). The concentration of bicarbonate $\left(\mathrm{HCO}_{3}\right)$ in water was determined by titration with $0.02 \mathrm{~N}$ sulfuric acid on the day of sampling before filtration. The methyl orange end-point titration was used with the final $\mathrm{pH}$ being 4.2-4.4.
Stable isotope analysis

The stable hydrogen $\left(\delta^{2} \mathrm{H}, \delta \mathrm{D}\right)$ and oxygen $\left(\delta^{18} \mathrm{O}\right)$ isotopes in surface water and groundwater were analyzed in the Key Laboratory of Water Cycle and Related Land Surface Processes of the Institute of Geographic Sciences and Natural Resources Research (IGSNRR), Chinese Academy of Sciences (CAS). The laser spectroscopic analysis of liquid water samples (DLT-100, Los Gatos Research Inc., USA) was used to carry out the isotopic measurements and the results were expressed conventionally as $\delta$ values, representing deviation in per mil (\%o) from the isotopic composition of a specified standard (Vienna Standard Mean Ocean Water, VSMOW),

$\delta^{18} \mathrm{O}(\delta \mathrm{D})=1,000 \times\left[\left(R_{\text {sample }} / R_{\text {standard }}\right)-1\right]$,

where $R$ refers to ${ }^{2} \mathrm{H} /{ }^{1} \mathrm{H}$ or ${ }^{18} \mathrm{O} /{ }^{16} \mathrm{O}$ ratios in both sample and standard. The measurement accuracy was consistently $\pm 1 \%$ for $\delta \mathrm{D}$ and $\pm 0.2 \%$ for $\delta^{18} \mathrm{O}$, respectively. The deuterium excess $(d)$ was calculated by the equation:

$d=\delta \mathrm{D}-8 \delta^{18} \mathrm{O}$.

Major ion analysis

The major ions of water samples were analyzed in the physical and chemical analysis center laboratory of the Institute of Geographic Sciences and Natural Resources Research (IGSNRR), Chinese Academy of Sciences (CAS). Cation (Ca, Mg, Na, K) analysis of water samples was performed by inductively coupled plasma optical emission spectrometry (ICP-OES) (Perkin-Elmer Optima $5300 \mathrm{DV}$, USA). Major anions $\left(\mathrm{Cl}, \mathrm{NO}_{3}, \mathrm{SO}_{4}\right)$ were analyzed on ion chromatography (IC) (Shimadzu LC-10ADvp, Japan). The limits of detection of ICP-OES and IC are $1 \mu \mathrm{g} / \mathrm{L}$ and $1 \mathrm{mg} / \mathrm{L}$, respectively. Analytical precision for major ions was within $1 \%$. For all water samples, ion balance errors (IBE) were $<10 \%$ and most of them were $<5 \%$. The total dissolved solid (TDS) was analyzed by the AquaChem (Schlumberger Water Services). 


\section{Results}

Field measurement indices

The results of field measurement indices, including electrical conductivity (EC), $\mathrm{pH}$, water temperature $(\mathrm{T})$, oxidation-reduction potential (ORP) and dissolved oxygen (DO), are shown in the Table 1 . The mean values of $\mathrm{pH}, \mathrm{T}$, ORP and DO of the surface water $\left(7.93,21.4^{\circ} \mathrm{C}, 143 \mathrm{mV}\right.$, $3.62 \mathrm{mg} / \mathrm{L})$ were larger than the groundwater $\left(7.21,9.6^{\circ} \mathrm{C}\right.$, $40 \mathrm{mV}, 2.04 \mathrm{mg} / \mathrm{L})$, respectively. However, the mean value of EC of groundwater $(721.0 \mu \mathrm{S} / \mathrm{cm})$ was larger than that of surface water $(502.0 \mu \mathrm{S} / \mathrm{cm})$. The standard deviations of T, ORP and DO of groundwater water $\left(3.2^{\circ} \mathrm{C}\right.$, $119.2 \mathrm{mV}, 1.19 \mathrm{mg} / \mathrm{L})$ were larger than those of surface water $\left(2.0{ }^{\circ} \mathrm{C}, 30.2 \mathrm{mV}, 0.58 \mathrm{mg} / \mathrm{L}\right)$, while the standard deviations of $\mathrm{pH}$ and $\mathrm{EC}$ of the surface water (0.6, $856.6 \mu \mathrm{S} / \mathrm{cm})$ were larger than the groundwater $(0.4$, $583.7 \mu \mathrm{S} / \mathrm{cm})$.

The mean values and standard deviations of $\mathrm{pH}$ of the river water, lake water, shallow groundwater and deep groundwater were $7.66,8.40,7.15,7.39$, and 0.18 , $1.04,0.29,0.54$, respectively. The lake water SN15 $(\mathrm{pH}=9.37)$ was the most alkaline, while the shallow groundwater SN22 ( $\mathrm{pH}=6.72)$ was the most acidic. The mean values and standard deviations of water temperature of the river water, lake water, shallow groundwater and deep groundwater were: 21.3, 20.4, 8.6 and $10.9{ }^{\circ} \mathrm{C}$; and $2.2,1.6,2.2$ and $3.6^{\circ} \mathrm{C}$, respectively. The river water $\operatorname{SN} 12\left(T=24.3^{\circ} \mathrm{C}\right)$ was the warmest, while the deep groundwater SN25 $\left(T=5.3{ }^{\circ} \mathrm{C}\right)$ was the coldest. The mean values and standard deviations of $\mathrm{EC}$ of the river water, lake water, shallow groundwater and deep groundwater were: $168.9,1,358.2,852.1$ and $508.3 \mu \mathrm{S} / \mathrm{cm}$; and $52.9,1,437.3,681.5$ and $220.1 \mu \mathrm{S} / \mathrm{cm}$, respectively. The electrical conductivity of lake water SN15 (EC $=2,830.0 \mu \mathrm{S} / \mathrm{cm}$ ) was the largest, while the lake water SN26 $(\mathrm{EC}=43.9 \mu \mathrm{S} / \mathrm{cm})$ was the least.

The mean values and standard deviations of ORP of the river water, lake water, shallow groundwater and deep groundwater were: 152, 140, 44 and $15 \mathrm{mV}$; and $27 \mathrm{mV}$, $43 \mathrm{mV}, 125 \mathrm{mV}$ and $106 \mathrm{mV}$, respectively. The value of ORP of shallow groundwater SN35 $($ ORP $=217 \mathrm{mV})$ was the largest, while the value of deep groundwater SN16 $(\mathrm{ORP}=-144 \mathrm{mV})$ was the least. The mean values and standard deviations of DO of river water, lake water, shallow groundwater and deep groundwater were 3.45, $3.92,2.14,1.55 \mathrm{mg} / \mathrm{L}$, and $0.64,0.42,1.16,0.84 \mathrm{mg} / \mathrm{L}$, respectively. The content of DO in the shallow groundwater SN27 (DO $=4.62 \mathrm{mg} / \mathrm{L})$ was the largest, and the value of DO of the deep groundwater SN09 $(\mathrm{DO}=0.59 \mathrm{mg} / \mathrm{L})$ was the least.
Stable isotopic composition

The mean values of $\delta^{18} \mathrm{O}$ and $\delta \mathrm{D}$ of surface water and groundwater were: -9.4 and $-75.1 \%$; and -10.5 and $-78.6 \%$, respectively. The mean values and standard deviations of stable oxygen isotope in the river water, lake water, shallow groundwater and deep groundwater were: $-11.2,-5.2,-10.3$ and $-10.8 \%$; and $0.8,2.7,0.9$ and $1.0 \%$, respectively (Table 1). The most isotopically enriched water was the lake water $\mathrm{SN} 37 \quad\left(\delta^{18} \mathrm{O}=\right.$ $-2.5 \%$ ), while the most depleted was the deep groundwater SN17 $\left(\delta^{18} \mathrm{O}=-13.1 \%\right.$ ).

The lake and wetland water samples were isotopically enriched. The reservoir water in the upper reaches was more isotopically depleted than the nearby river water. The river waters in the lower reaches were more isotopically enriched than the river water in the upper reaches. The shallow groundwater was more isotopically enriched than the deep groundwater. The most depleted water sample SN17 (well depth was $106 \mathrm{~m}$ ) was sampled in Qiqihaer City, with the $\delta^{18} \mathrm{O}$ value $-13.1 \%$.

\section{Hydrochemical composition}

The concentrations of major ions in the surface water and groundwater are shown in Table 1. The mean values and standard deviations of the total dissolved solids (TDS) of the surface water and groundwater were $265.1,416.5 \mathrm{mg} / \mathrm{L}$ and $315.8,335.8 \mathrm{mg} / \mathrm{L}$, respectively. The total dissolved solids in the groundwater were greater than those of surface water. The TDS value of the shallow groundwater SN40 (TDS $=1,532.0 \mathrm{mg} / \mathrm{L})$ was the largest, while the TDS value of the lake water SN26 (TDS $=25.4 \mathrm{mg} / \mathrm{L}$ ) was the least. The mean values and standard deviations of TDS of the river water, lake water, shallow groundwater and deep groundwater were: $197.7,493.4,498.8$ and $285.4 \mathrm{mg} / \mathrm{L}$; and 207.4, 516.1, 377.0 and $180.1 \mathrm{mg} / \mathrm{L}$, respectively.

The mean values and standard deviations of the major cations ( $\mathrm{Ca}, \mathrm{Mg}, \mathrm{Na}, \mathrm{K}$ ) in the surface water were: 18.5, 7.5, 87.3 and $3.8 \mathrm{mg} / \mathrm{L}$; and 7.7, 6.5, 198.4 and $2.9 \mathrm{mg} / \mathrm{L}$, respectively. The mean values and standard deviations of the major cations $(\mathrm{Ca}, \mathrm{Mg}, \mathrm{Na}, \mathrm{K}$ ) in the groundwater were: 61.1, 17.9, 69.9 and $3.2 \mathrm{mg} / \mathrm{L}$; and 50.1, 14.7, 100.1 and $6.5 \mathrm{mg} / \mathrm{L}$, respectively. The mean concentrations of calcium and magnesium in the groundwater were larger than those of the surface water; however, the mean concentrations of sodium and potassium in the surface water were larger than the groundwater. The maximum content of sodium in the surface water was in lake water SN15 $(\mathrm{Na}=619.1 \mathrm{mg} / \mathrm{L})$, followed by lake water $\mathrm{SN} 37$ $(\mathrm{Na}=527.8 \mathrm{mg} / \mathrm{L})$. The maximum content of sodium in the groundwater was in shallow groundwater SN11 $(\mathrm{Na}=490.4 \mathrm{mg} / \mathrm{L})$. The minimum concentration of 


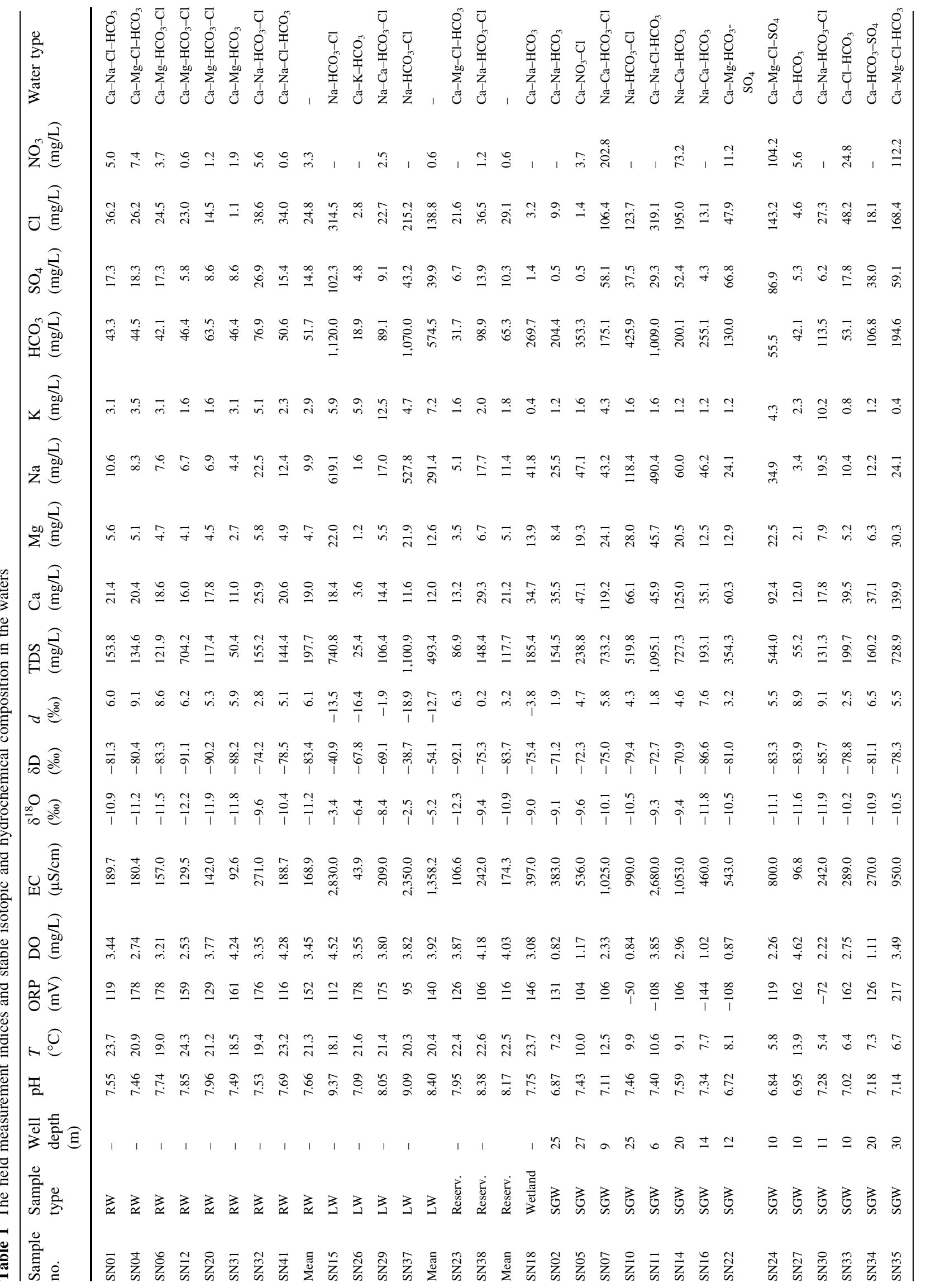




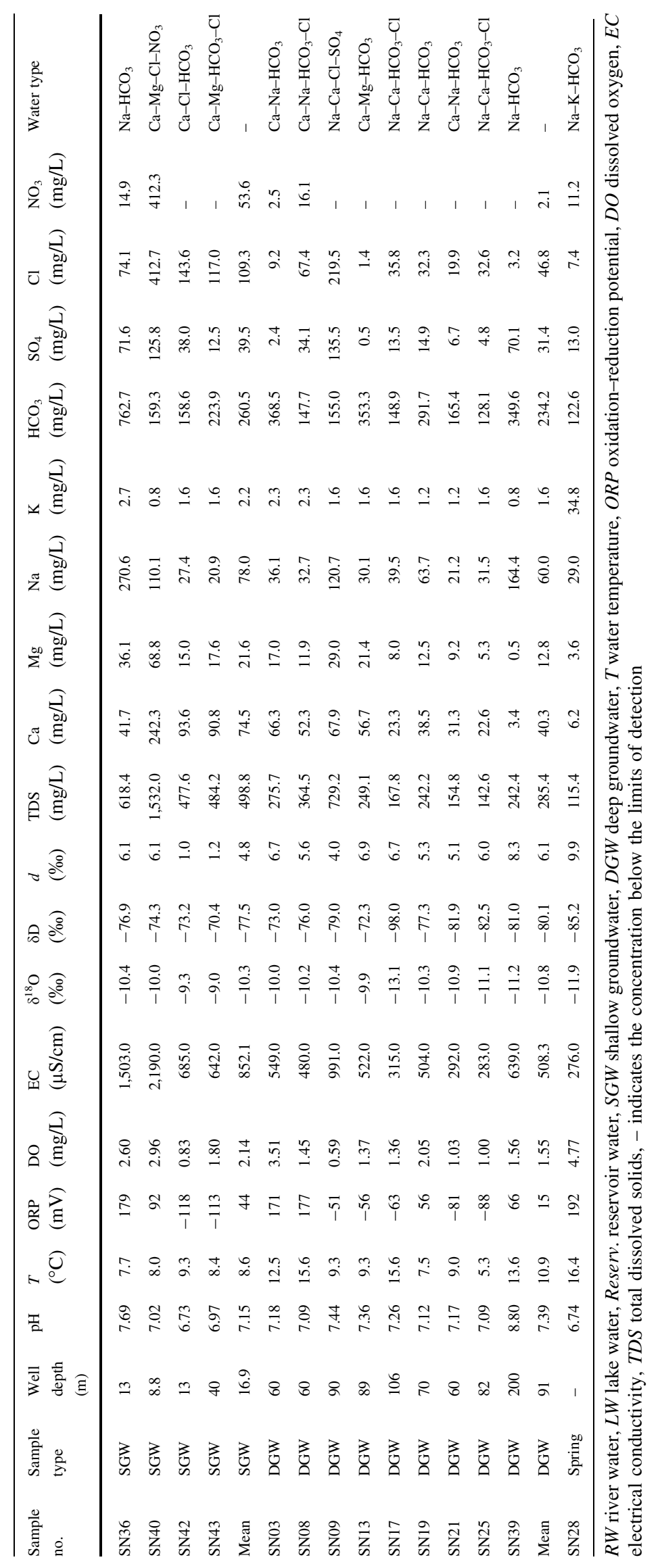


sodium in the surface water was in lake water SN26 $(\mathrm{Na}=1.6 \mathrm{mg} / \mathrm{L})$, which was followed by river water $\mathrm{SN} 31(\mathrm{Na}=4.4 \mathrm{mg} / \mathrm{L})$. The minimum concentration of sodium in the groundwater was in groundwater SN27 $(\mathrm{Na}=3.4 \mathrm{mg} / \mathrm{L})$.

The mean concentrations of major anions in the groundwater were greater than those of the surface water. The mean values and standard deviations of the major anions $\left(\mathrm{HCO}_{3}, \mathrm{SO}_{4}, \mathrm{Cl}, \mathrm{NO}_{3}\right)$ in the surface water were: 207.5, 20.0, 54.3 and $2.0 \mathrm{mg} / \mathrm{L}$; and $365.3,25.0,88.4$ and $2.4 \mathrm{mg} / \mathrm{L}$, respectively. The mean values and standard deviations of the major anions $\left(\mathrm{HCO}_{3}, \mathrm{SO}_{4}, \mathrm{Cl}, \mathrm{NO}_{3}\right)$ in the groundwater were: 244.8, 35.9, 85.8 and $35.5 \mathrm{mg} / \mathrm{L}$; and 209.8, 37.1, 102.2 and $87.3 \mathrm{mg} / \mathrm{L}$, respectively. The maximum content of bicarbonate in the surface water and groundwater were in lake water $\mathrm{SN} 15\left(\mathrm{HCO}_{3}=1,120.0 \mathrm{mg} / \mathrm{L}\right)$ and in shallow groundwater SN11 $\left(\mathrm{HCO}_{3}=1,009.0 \mathrm{mg} / \mathrm{L}\right)$, respectively. The minimum concentration of bicarbonate was in lake water $\mathrm{SN} 26\left(\mathrm{HCO}_{3}=18.9 \mathrm{mg} / \mathrm{L}\right)$, which was followed by river water SN06 and groundwater SN27 $\left(\mathrm{HCO}_{3}=42.1 \mathrm{mg} / \mathrm{L}\right)$.

\section{Discussion}

Relationship between surface water and groundwater

The scatter plots of $\delta \mathrm{D}$ and $\delta^{18} \mathrm{O}$ indicate the relationship between surface water and groundwater (Fig. 4). The local evaporation line (LEL) of surface water is $\delta \mathrm{D}=5.2$ $\delta^{18} \mathrm{O}-26.3$, while the local meteoric water line (LWML) is $\delta \mathrm{D}=7.46 \delta^{18} \mathrm{O}+0.90$ (Liu et al. 2010). The lake water samples (SN37, SN15) locate in the right top area of the figure, indicating that lake water strongly evaporated. The evaporated lake water samples (SN26, SN29) also locate in the right top area, but lake water SN29 is close to the

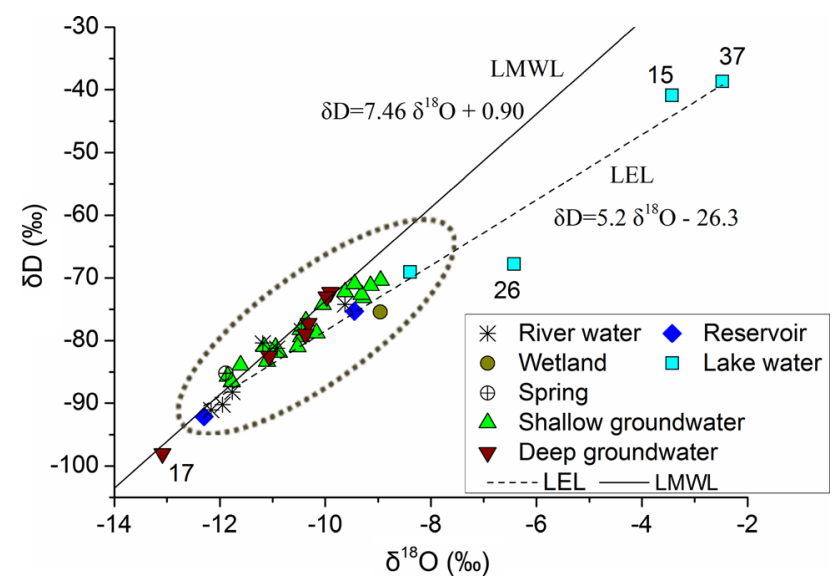

Fig. 4 The relationship of $\delta \mathrm{D}$ vs. $\delta^{18} \mathrm{O}$ in the surface water and groundwater shallow groundwater samples. The most depleted water is deep groundwater SN17, which is at the left bottom area of the figure. The depleted reservoir water SN23 is close to the river water samples and also locates in the left bottom area of the figure.

The surface water and groundwater in the plain recharge from the precipitation, and the water originates from the mountain areas (Chen et al. 2010). The stable isotope data of the cross point between LMWL and LEL is depleted, indicating that the isotopic composition in the recharge source is depleted (Fig. 4). Although most water samples were recharged by depleted water, the relationship between surface water and groundwater was different. The groundwater table of water sample SN02 was $113 \mathrm{~m}$, and the surface water level of water sample SN01 was $112 \mathrm{~m}$ at Haerbin City. Consequently, the groundwater (SN02) may discharge to the Songhua River (SN01). The oxygen stable isotope and two components approach could be applied to calculate the percentages of groundwater and surface water in the mixed component (Zhang et al. 2014). The contributions of the shallow groundwater (SN02) and upper reaches river water (SN04) were 14 and $86 \%$, respectively. The surface water and groundwater connectivity is weakened by the clay layer and the discontinuous aquifer.

Hydrochemical evolution of surface water and groundwater

The piper diagram is widely used to present and classify the major ions of water. The water type of shallow groundwater is complex. Most river waters are of $\mathrm{Ca}-\mathrm{Mg}-$ $\mathrm{HCO}_{3}(\mathrm{Cl})$ type, and most deep groundwaters are of $\mathrm{Ca}(\mathrm{Na})-\mathrm{HCO}_{3}$ type. The water type of wetland is $\mathrm{Ca}-\mathrm{Na}-$ $\mathrm{HCO}_{3}$ (Table 1). The water type of the water samples in the green circle (the bottom of the rhombus diagram) is $\mathrm{Na}-\mathrm{HCO}_{3}$. The water type of the water samples in the red circle (the top of the rhombus diagram) is $\mathrm{Ca}-\mathrm{Mg}-\mathrm{Cl}$. The other water samples are $\mathrm{Ca}-\mathrm{Mg}-\mathrm{HCO}_{3}$ (Fig. 5). Water evolution proceeds from $\mathrm{Ca}-\mathrm{Mg}-\mathrm{HCO}_{3}$ to $\mathrm{Na}-\mathrm{HCO}_{3}$ by the evaporation and ion exchange of calcium in the water for the sodium in the soil (Edmunds et al. 1982; Edmunds 2003; Zhang et al. 2007).

The diagrams of the ratios between TDS and $\mathrm{Na}^{+} /$ $\left(\mathrm{Na}^{+}+\mathrm{Ca}^{2+}\right)$, and TDS and $\mathrm{Cl}^{-} /\left(\mathrm{Cl}^{-}+\mathrm{HCO}_{3}{ }^{-}\right)$show the mechanisms controlling water chemistry (Fig. 6). The chemicals in natural waters are from three different origins: atmospheric precipitation, rock dominance and the evaporation-crystallization process (Gibbs 1970; Zhu and Yang 2007). The water samples are located in the transitions between weathering of rocks and evaporation-precipitation. Most surface waters (river, reservoir, lake) and some groundwater samples are close to the zone of rock dominance, while some lake and groundwater samples are in the 
Fig. 5 The piper diagram of the surface water and groundwater

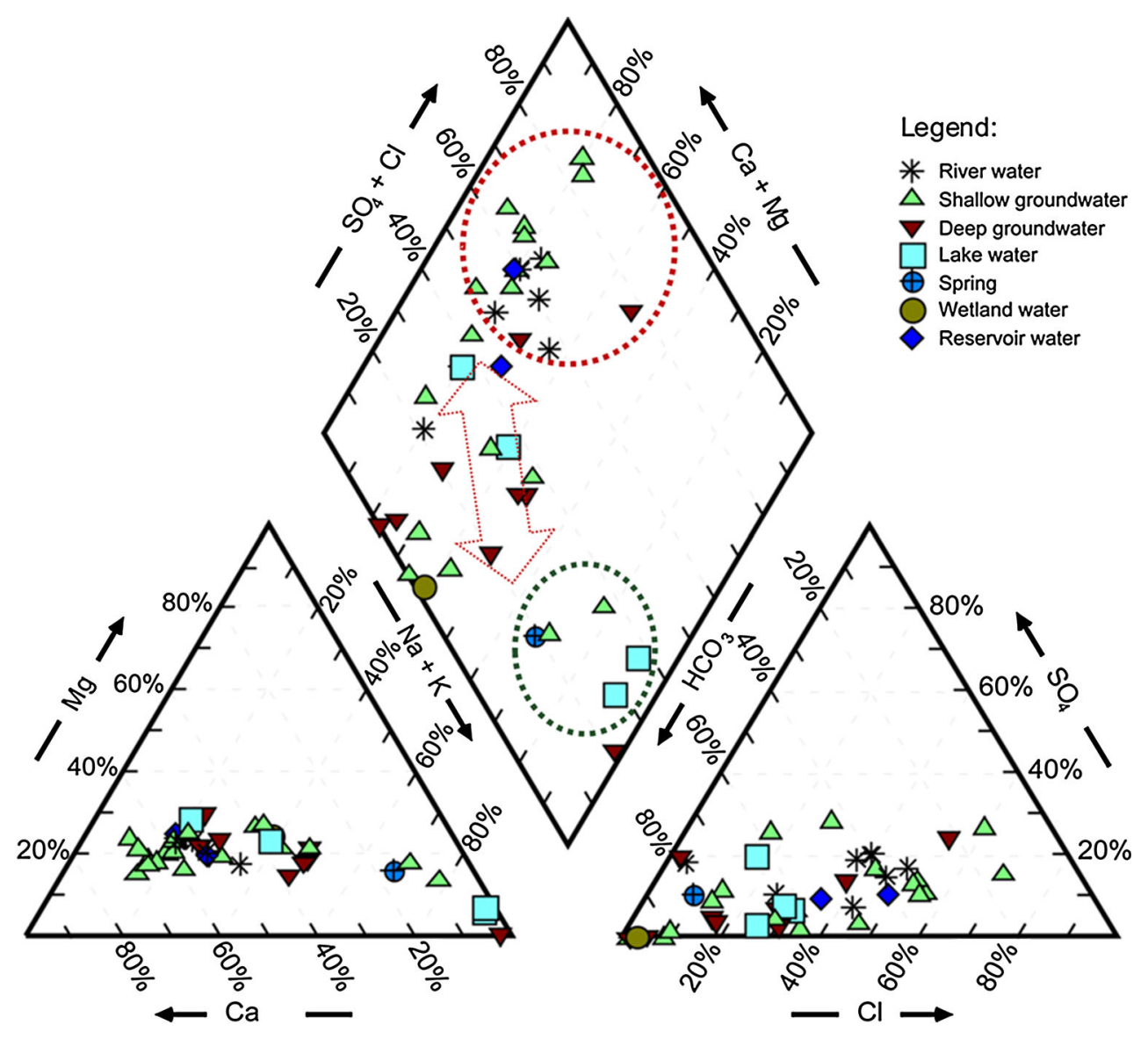

Fig. 6 The Gibbs diagrams of the surface water and groundwater
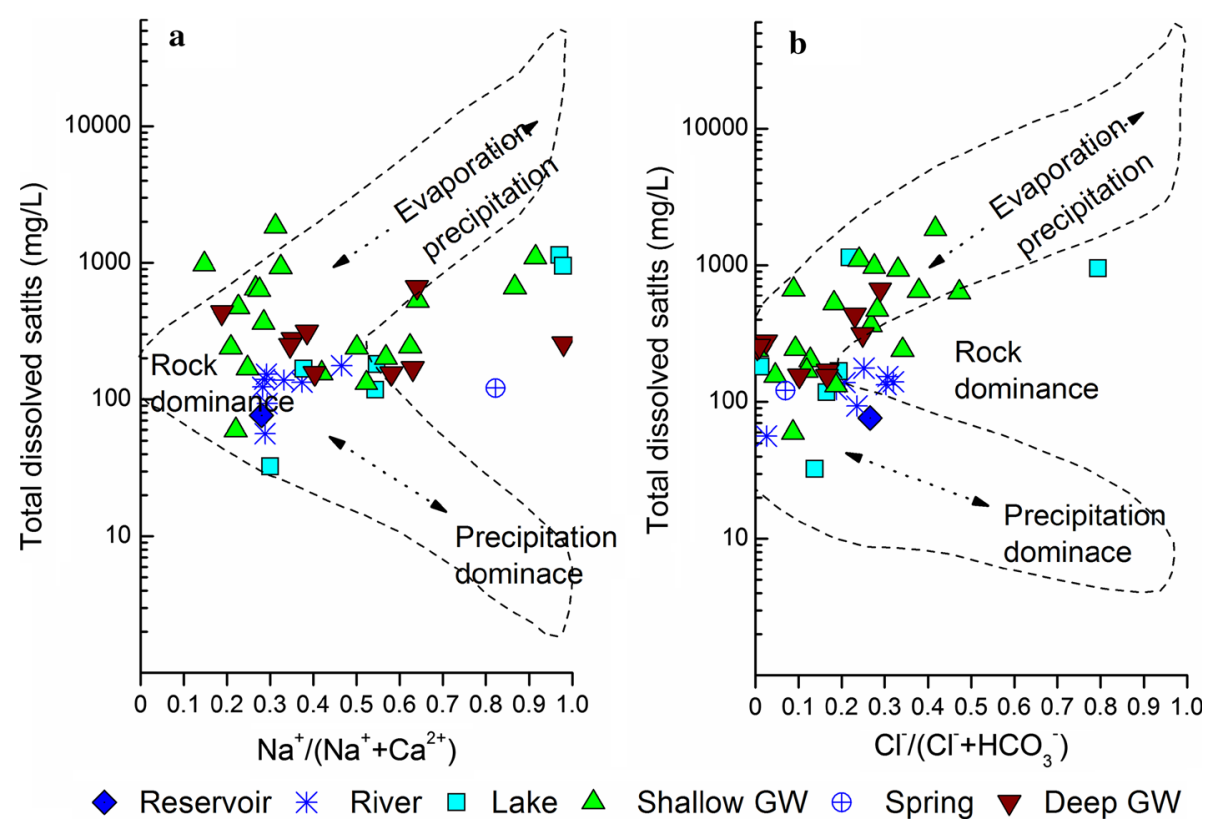

Reservoir * River $\square$ Lake $\triangle$ Shallow GW $\oplus$ Spring $\nabla$ Deep GW

evaporation-precipitation controlling area. The piper and Gibbs diagrams show that the water-rock interaction is the main factor of water evolution. The concentration of ions in the groundwater is the result of the weathering-dissolution of mineral with the length of flow and residence time. The elevated concentration of sodium is due to the 


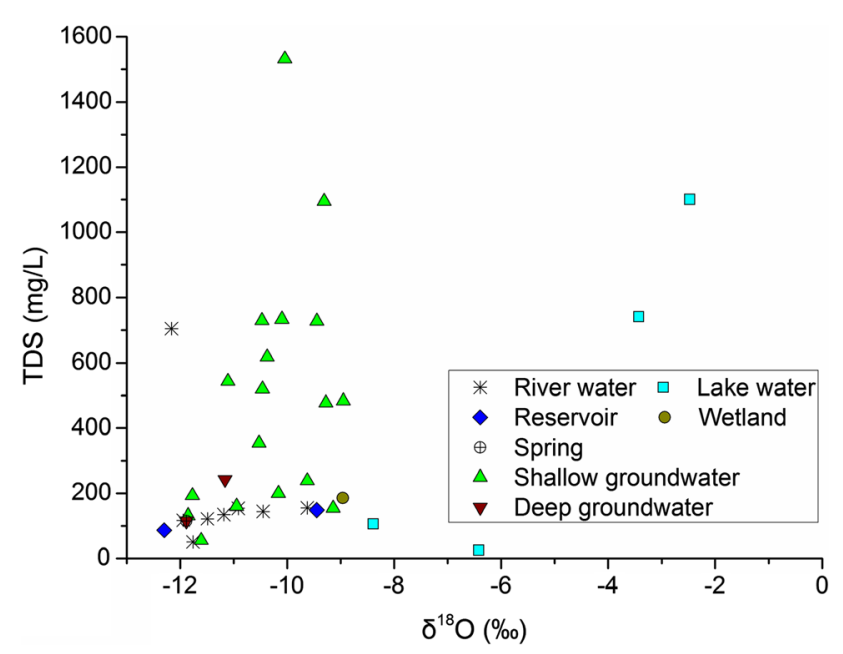

Fig. 7 The relationship between TDS and $\delta^{18} \mathrm{O}$ of the surface water and groundwater

weathering-dissolution mechanism of halite strata and the release from feldspar during the groundwater flow (Zhang et al. 2007).

The $\delta^{18} \mathrm{O}$ value increases with an increase in salinity (TDS) under evaporation (Zhang et al. 2007). The TDS$\delta^{18} \mathrm{O}$ relationship shows that the water follows a trend of salinity increase with a slight isotopic enrichment (Fig. 7). The groundwater flows very slowly, and groundwater levels vary with seasonal changes. The frequent up and down movements of soil water are very active (Wang et al. 2009). The major mechanism responsible for groundwater salinization is mainly from leaching of the surficial or nearsurface salts present in the saline-alkaline soil during vertical recharge from backwater and irrigation water (Zhang et al. 2007). The water evaporation and leaching of saline-alkaline soil are the main reasons for water salinity.

\section{Water management}

The Songnen Plain is one of the major distribution regions of soda saline-alkali soil. The salinity of water is the key problem to the water management. Stable isotopes were used to study the relationship between surface water and groundwater. In combination with hydrochemical analyses, water evolution and water salinity were discussed for water management. Water evaporation and leaching of salinealkaline soil are the main reasons for water salinity. Surface water and groundwater are suitable for agricultural irrigation; however, the control of sodium and salinity hazard is required (Zhang et al. 2012). Irrigation techniques, such as drip irrigation, can be applied for sustainable reclamation of salt-affected soil (Liu et al. 2011). The surface water can be used directly; however, groundwater with high salinity should be controlled to reduce the sodium and salinity hazard.

\section{Conclusions}

The relationship between, and hydrochemical evolution of, surface water and groundwater is the basis for water management. The surface water and groundwater were sampled for stable isotopes and hydrochemistry analyses. The stable isotopic composition indicates that the water in the plain is recharged not only from the precipitation, but also from water originating from the mountain areas. The connectivity between surface water and groundwater is weak, because of the clay layer and the discontinuous aquifer in the Songnen Plain. The water evolution is from $\mathrm{Ca}-\mathrm{Mg}-\mathrm{HCO}_{3}$ to $\mathrm{Na}-\mathrm{HCO}_{3}$ by evaporation, water-rock interaction and ion exchange processes. Water evaporation and leaching of saline-alkaline soil are the main reasons for water salinity in the Songnen Plain.

The groundwater flows from the mountain areas into the central basin slowly. Soil alkalization is very active, since the groundwater table is close to the land surface. The leaching of salts in the saline-alkaline soil during recharging from backwater and irrigation water intensifies water salinization. To maintain the environment and for sustainable development, water resources should be used reasonably. Surface water can be used directly; however, groundwater with high salinity should be controlled. Irrigation techniques, such as drip irrigation, can be applied for sustainable reclamation of salt-affected soil. The relationship between and evolution of surface water and groundwater provide important guidance not only for water management in the arid and semi-arid regions, but also for the soda saline-alkali soil regions in the world.

Acknowledgments This research was supported by the Main Direction Program of Knowledge Innovation of the Chinese Academy of Sciences (No. KZCX2-YW-Q06-1), the Key Program of National Natural Science Foundation of China (No. 40830636), the Innovation Team Training Plan of the Tianjin Education Committee (TD125037) and the Doctoral Found of Tianjin Normal University (52XB1401). We sincerely thank the editor and anonymous reviewers for comments that greatly improved this paper.

\section{References}

Anderson EI (2005) Modeling groundwater-surface water interactions using the Dupuit approximation. Adv Water Resour 28(4):315-327

Ayenew T, Kebede S, Alemyahu T (2008) Environmental isotopes and hydrochemical study applied to surface water and groundwater interaction in the Awash River basin. Hydrol Process 22(10):1548-1563 
Banks EW, Simmons CT, Love AJ, Shand P (2011) Assessing spatial and temporal connectivity between surface water and groundwater in a regional catchment: implications for regional scale water quantity and quality. J Hydrol 404:30-49. doi:10.1016/j. jhydrol.2011.04.017

Baskaran S, Ransley T, Brodie RS, Baker P (2009) Investigating groundwater-river interactions using environmental tracers. J Geol Soc Aust 56(1):13-19

Bruce JP (2011) Protecting groundwater: the invisible and vital resource. Backgrounder, no 136. C.D. Howe Institute, Toronto

Chen Z, Wei W, Liu J, Wang Y, Chen J (2010) Identifying the recharge sources and age of groundwater in the Songnen Plain (Northeast China) using environmental isotopes. Hydrogeol $\mathrm{J}$ 19(1):163-176. doi:10.1007/s10040-010-0650-9

Edmunds W (2003) Groundwater evolution in the Continental Intercalaire aquifer of southern Algeria and Tunisia: trace element and isotopic indicators. Appl Geochem 18(6):805-822. doi:10.1016/s0883-2927(02)00189-0

Edmunds WM, Bath AH, Miles DL (1982) Hydrochemical evolution of the East Midlands Triassic sandstone aquifer, England. Geochimica et Cosmochimica Acta 46(11):2069-2081

Gibbs RJ (1970) Mechanisms controlling world water chemistry. Science 170(3962):1088-1090

Heilongjiang land reclamation bureau (ed) (2009) Statistical yearbook of Heilongjiang reclamation area. China Statistics Press, Beijing

Li B, Zhou C (2001) Sandy desertification in west of Northeast China plain in the past 10 years (in Chinese). Acta Geographica Sinica 56(3):307-315

Liu J, Song X, Yuan G, Sun X, Liu X, Wang S (2010) Characteristics of $\delta^{18} \mathrm{O}$ in precipitation over eastern monsoon China and the water vapor sources. Chin Sci Bull 55(2):200-211

Liu S, Kang Y, Wan S, Wang Z, Liang Z, Sun X (2011) Water and salt regulation and its effects on Leymus chinensis growth under drip irrigation in saline-sodic soils of the Songnen Plain. Agr Water Manag 98(9):1469-1476. doi:10.1016/j.agwat.2011.04. 016

Sophocleous M (2002) Interactions between groundwater and surface water: the state of the science. Hydrogeol J 10(1):52-67

Wang H, Wan Z, Yu S, Luo X, sun G (2004) Catastrophic ecoenvironmental change in the Songnen plain, northeastern China since 1900s. Chin Geogr Sci 14(2):179-185
Wang L, Seki K, Miyazaki T, Ishihama Y (2009) The causes of soil alkalinization in the Songnen Plain of Northeast China. Paddy Water Environ 7(3):259-270. doi:10.1007/s10333-009-0166-X

Winter TC, Harvey JW, Franke OL, Alley WM (1998) Ground water and surface water: a single resource. Diane Pub Co, Denver

Woessner WW (2000) Stream and fluvial plain ground water interactions: rescaling hydrogeologic thought. Groundw 38(3): $423-429$

Xiao C, Liang X, Zhang F, Feng B, Xie S (2009) Groundwater numerical simulation of multi-aquifers in Songnen plain. In: Zhang CK, Tang HW (eds) Advances in Water Resources and Hydraulic Engineering, pp 214-218

Yuan L (2006) Hydrochemistry of the groundwater in Songnen plain (in Chinese). Geol Resour 15 (2):122-125,132

Zhang DF, Wang SJ (2001) The process and driving forces of ecogeo-environmental evolution of the Songnen Plain in northeast China since the Quaternary. Environ Geol 40(11-12):1362-1366

Zhang J, Zhang P, Chi Y (1991) The situation and countermeasures of groundwater resource in Songnen plain (in Chinese). Heilongjiang Sci Technol Water Conserv 4:1-5

Zhang GX, Deng W, Yang YS, Salama RB (2007) Evolution study of a regional groundwater system using hydrochemistry and stable isotopes in Songnen Plain, Northeast China. Hydrol Process 21(8):1055-1065

Zhang B, Song X, Zhang Y, Han D, Tang C, Yu Y, Ma Y (2012) Hydrochemical characteristics and water quality assessment of surface water and groundwater in Songnen plain, Northeast China. Water Res 46(8):2737-2748. doi:10.1016/j.watres.2012. 02.033

Zhang B, Song X, Zhang Y, Han D, Tang C, Yang L, Wang Z, Liu T (2014) A study of the interrelation between surface water and groundwater using isotopes and chlorofluorocarbons in Sanjiang plain, Northeast China. Environ Earth Sci. doi:10.1007/s12665014-3279-5

Zhao H, Zhang Z, Chen Y (2010) Lowering of groundwater level and its negative environment effects in the Songnen Plain (in Chinese). J Arid Land Resour Environ 24(1):126-130

Zhu B, Yang X (2007) The ion chemistry of surface and ground waters in the Taklimakan Desert of Tarim Basin, western China. Chin Sci Bull 52(12):2123-2129. doi:10.1007/s11434-007-0298-6 